\title{
The difference of surface coarseness of high-copper amalgam restoration material before and after $38 \%$ hydrogen peroxide application by in vitro in-office bleaching technique
}

\author{
Nurmala Gustina, Setiawan Natasasmita, Dudi Aripin \\ Department of Conservative Dentistry Faculty of Dentistry Universitas Padjadjaran
}

\begin{abstract}
Hydrogen peroxide is an effective agent to take off tooth colouring. This bleaching agent can cause microstructural change on amalgam restoration surfaces. The aim of this research is to know the difference of surface roughness of high-copper amalgam restoration materials before and after $38 \%$ hydrogen peroxide application by in-office bleaching technique. The sample was used consist of ten specimens of high-copper amalgam restorations which was applied by hydrogen peroxide $38 \%$. The surface rougness was measured by surface tester (Surtronic 3P). The result of this research was reach by $t$-test paired calculation is the differences of surface roughness of amalgam restorations before and after first 15 minutes either second 15 minutes hydrogen peroxide 38\% application didn't show significant differences. The conclusion of this research is no statistically significant difference of surface roughness of high-copper amalgam restoration materials before and after 38\% hydrogen peroxide application by in-office bleaching technique.
\end{abstract}

Key words: Surface coarseness, high-copper amalgam, bleaching, hydrogen peroxide

\section{INTRODUCTION}

Tooth has a role in constructing face esthetic and personality. One of the factors that influence tooth esthetic is tooth discoloration. Many individuals are yearning for white, clean and healthy teeth as those may help them to be more confident when communicating with others. ${ }^{1}$

Tooth discoloration is an esthetic issue that can influence people's appearance and may bring a negative psychological effect for the people. In keeping with that fact, today dentistry has given more consideration towards esthetic. One of the techniques used is tooth whitening or bleaching. Bleaching is a part of efforts to overcome tooth discoloration in order to get normal and wellcolored teeth using a strong oxidant. ${ }^{2}$

Bleaching technique can be differentiated according to tooth vitality, that is intracoronal bleaching and extracoronal bleaching. Intracoronal bleaching technique is a whitening method of non vital tooth that has underwent root canal treatment by placing a strong oxidant inside the pulp chamber, whereas extracoronal bleaching technique is a whitening method of vital tooth underwent discoloration. ${ }^{1}$ 
Generally, extracoronal bleaching technique comprises of home bleaching and in-office bleaching. Home bleaching technique is more frequently used than in-office bleaching technique, due to its simplicity, practicality, low cost, and it can be performed at home by an individual. Some individuals want their teeth to be whiter in such a brief time, so in-office bleaching technique is the main treatment alternative for tooth whitening. This is made possible with the use of a highly concentrated bleaching agent and light or heat in order to accelerate the chemical reaction. ${ }^{3}$

The utilization of a highly concentrated and strong oxidant bleaching agent may lead a side effect. According to McGuckin et al. ${ }^{4}$ after bleaching with $30 \%$ hydrogen peroxide, there is a change in tooth enamel morphology. This is supported by Wattanapayungkul and Yap ${ }^{5}$ who stated that hydrogen peroxide with high concentration causes coarseness on tooth surface.

Besides its effect on tooth hard tissue, bleaching agent application may also affect amalgam restoration. ${ }^{6}$ Amalgam restoration material is usually used as the restoration material for posterior teeth, whereas bleaching agent is applied on the anterior teeth. However, particularly for an individual with a wide smile line, it will generate a perception of anterior teeth region to be more posterior so the amalgam restoration inside individual's oral cavity will contact with the bleaching agent. The bleaching agent contact with an amalgam restoration may increase susceptibility towards corrosion and degradation, mercury $(\mathrm{Hg})$ and silver release, as well as micro-structural changes of amalgam restoration material surface. ${ }^{7-10}$ This may lead to surface coarseness of amalgam restoration. Surface coarseness of amalgam restoration is one of the physical characteristics that are clinically important, since a coarse surface of amalgam restoration increases bacterial adhesion capacity, causes plaque retention, tooth discoloration, gingival inflammation, and caries. ${ }^{5}$

Based on the background research above, the author is interested in carrying out a study on the difference of surface coarseness of highcopper amalgam restoration material before and after $38 \%$ hydrogen peroxide application using in vitro in-office bleaching technique.

\section{MATERIALS AND METHODS}

Material: red wax (Anchor); decorative resin; cotton, high copper amalgam (SDI gs-80); artificial saliva; 38\% hydrogen peroxide gel (opalescence extra boost).

Tools: cylindrical pipe; caliper; timer; mixing jar and spatula; glass lab; amalgamator; amalgam stopper and burnisher; micromotor (strong 207) and contra angle; polishing instruments. 10). Pincher and explorer; syringe and chip blower; rubber glove and mask; surface tester (Surtronic 3P).

Procedure: (1) Amalgam restoration specimen was prepared; (2) The first coarseness test was done by putting the probe of tester surface onto the amalgam restoration surface, and then the start button was pushed to activate the tester. Afterwards, the average of surface coarseness of amalgam restoration was obtained; (3) Bleaching agent was mixed with activator agent, and pumped for 20 times. 38\% of hydrogen peroxide was then applied evenly with a thickness of $0.5-1 \mathrm{~mm}$ on the amalgam restoration, and left for 15 minutes. Thereupon, the region exposed with bleaching agent was cleaned by water and air sprays; (4) After the bleaching process was complete, the second coarseness test was done, that is a coarseness test after bleaching agent application; (5) Bleaching agent was re-applied for 15 minutes, and then it was cleaned by water and air sprays; (6) The third coarseness test was done; (7) All results were recorded and tested.

\section{RESULTS}

The average value of surface coarseness of high copper amalgam restoration material is shown in the Tab. 1 and diagram 1.

\section{DISCUSSION}

This study used 10 specimens of amalgam restoration that have been polished and soaked in artificial saliva. These ten specimens were given bleaching treatments twice with time interval of 15 minutes, and each treatment was measured by a surface tester.

Macroscopically, the surface of amalgam restoration before bleaching agent application 
Table 1. The differences of surface coarseness of high-copper amalgam restoration material before and after hidrogen peroxide application $38 \%$.

\begin{tabular}{|c|c|c|c|c|c|c|}
\hline Differences & $\begin{array}{l}\text { Differences of } \\
\text { average }(\mu \mathrm{m})\end{array}$ & $\begin{array}{l}\text { Deviation } \\
\text { standard }\end{array}$ & Sample & $t_{\text {count }}$ & $\mathrm{t}_{\text {table }}$ & Note \\
\hline Before-after $1^{\text {st }} 15$ minute & 0,258 & 0,561 & 10 & 1,454 & 2,262 & $\mathrm{H}_{0}$ - accepted \\
\hline After $1^{\text {st }} 15$ minute - after $2^{\text {nd }} 15$ minute & $-0,179$ & 0,541 & 10 & $-1,047$ & 2,262 & $\mathrm{H}_{0}-$ accepted \\
\hline Before-after $2^{\text {nd }} 15$ minute & 0,079 & 0,435 & 10 & 0,575 & 2,262 & $\mathrm{H}_{0}$ - accepted \\
\hline
\end{tabular}

Diagram 1. The average value of surface coarseness of high copper amalgam restoration material.

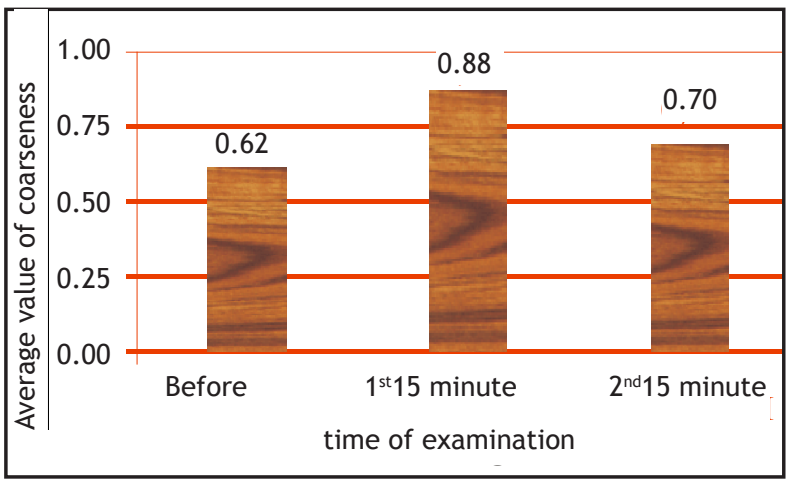

appeared soft and glossy. This condition was also seen on amalgam restoration after bleaching agent application.

Measurement using Surtronic 3P was carried out in order to find out the microscopic condition of the specimen. The result of this surface coarseness of amalgam restoration was then tested using paired t-test. The results are shown in Digram 1 and Tab.1 Based on the results, the hypothesis given by the author in the first chapter is accepted, i.e. there is no significant difference of surface coarseness of amalgam restoration before and after the first and the second 15 minutes of $38 \%$ hydrogen peroxide application.

This result is in accordance with the results of Silva et al. ${ }^{11}$ where there is a change in coarseness value before and after hydrogen peroxide application of high concentration, but the results was not statistically significant. Moreover, the study by Scemehorn et al. ${ }^{12}$ shows the same result when they used a Scanning Electron Microscope to evaluate the surface of admixed high-copper amalgam specimen with the application of tooth whitener gel containing $6 \%$ of hydrogen peroxide for 20 minutes as many as 28 treatments. Also, the results of the study by Ahn et al. ${ }^{13}$ show that there is no significant change in the morphology of amalgam surface treated using carbamide peroxide.

The process of coarseness change of amalgam restoration treated with an oxidant agent has yet to be firmly understood. As a rule, the surface coarseness of amalgam restoration inside the mouth occurs due to the process of abrasion resulted from mastication pressure, acidity, which is accelerated by the process of corrosion on the amalgam restoration. ${ }^{14}$ According to the previous studies, surface coarseness of amalgam restoration is related to micro-structural changes of amalgam restoration surface. Rostein et al. ${ }^{15}$ explained that oxidation, dissolution, and corrosion may occur on the surface of amalgam restoration treated with a bleaching agent. These three processes increase the release of $\mathrm{Hg}$ significantly.

According to a study by Al-Salehi et al. ${ }^{16}$ it is stated that despite the release of metal ions, SEM investigation and coarseness test using Talysurf show that, there is no significant coarseness on amalgam specimens. The average coarseness of the surface of cylindrical unicompositional spherical high-copper alloy amalgam specimens with a diameter of $10 \mathrm{~mm}$ and height of $2 \mathrm{~mm}$ after carbamide peroxide application is $2.23 \mu \mathrm{m}$ (0.47).

The release of metal ions on amalgam occurs from early manipulation and during inside the mouth. The $\mathrm{Hg}$ release occurs because of condensation, polishing, corrosion, acidity, and heating. ${ }^{8}$ The release of metal ions is also influenced by $\mathrm{pH}$, concentration, as well as exposure duration of the bleaching agents. ${ }^{17}$

The results of the study are not significant because since the beginning amalgamator was used in the manipulation to obtain plastic and homogeneous mass which will experience condensation easier. After 24 hours from condensation, polishing was then carried out. According to Svare and $\mathrm{Chan}^{18}$, polishing is intended to reduce surface microporosities, so it generates 
homogenous regions, as well as to reduce surface corrosion of amalgam. High-copper amalgam used in this study has more ability to resist the process of corrosion compared to low-copper alloy. This process of corrosion occurs when there is a temperature fluctuation, $\mathrm{pH}$ change, and the presence of electrolyte. ${ }^{19}$ In this study, amalgam specimen was soaked in saliva of $\mathrm{pH} 7$ and the bleaching agent used was 38\% hydrogen peroxide of $\mathrm{pH} 7$; so there was no $\mathrm{pH}$ change. In addition, the temperature used in the study was room temperature. Room temperature is lower than mouth temperature. This leads to slower process of corrosion.

According to Rotstein et al. ${ }^{17} \mathrm{pH}$ of bleaching agents is one of the factors that make the process of $\mathrm{Hg}$ dissolution significant. This is due to the fact that bleaching agents with low $\mathrm{pH}$ result in the loss of thin layer of oxide, so $\mathrm{Hg}$ will be oxidized and released to the solvent. Moreover, Soh et al. ${ }^{20}$ explained that $\mathrm{Hg}$ release at $\mathrm{pH} 2.5$ occurs more than of $\mathrm{pH} 7$.

Other factors that cause microstructural changes of amalgam restoration are the concentration of the hydrogen peroxide and the exposure duration on the surface of amalgam restoration. Highly concentrated bleaching agent used in this study, i.e. 38\% hydrogen peroxide. According to Certosimo et al. ${ }^{10}$ the increased concentration of hydrogen peroxide results in increased oxidation, corrosion, and dissolution processes of amalgam restorations. Based on the duration of hydrogen peroxide exposure, i.e. 15 minutes for each procedure (based on the manufacturer's recommendation) there was no change of coarseness on amalgam surface. Rotstein ${ }^{15}$ explained that micro-structural changes occur in prolonged bleaching treatments. This is due to fact that the more bleaching agents contact the amalgam, the more oxidation and dissolution processes occur on the surface of the amalgam.

According to Rismanto ${ }^{3}$, in office bleaching technique, generally tooth whitening takes place more or less one hour, with bleaching agent application of two or three times. Therefore, the author carried out two 38\% hydrogen applications to find out whether more frequent bleaching agent application will affect the coarseness of amalgam restoration material. However, the results of the second exposure did not show any significant change.

This bleaching agent is chemical-activated, that is the agent is activated using a chemical substance and the activation can be achieved without radiation. According to Rismanto et al. ${ }^{3}$ radiation will accelerate hydrogen peroxide dissociation and increases the temperature of bleaching agents. Increased temperature may lead to corrosion process of amalgam restorations.

Another factor that makes the results to be insignificant is the use of fresh amalgam specimens. The purpose of this is to reduce intervening factors in the study. Amalgam restoration which has been already inside the mouth may probably have experienced $\mathrm{Hg}$ release and abrasion as the result of activities in the mouth cavity. In addition, the process of corrosion may also have happened.

Based on discussion above, it is proven that $38 \%$ hydrogen peroxide application did not significantly cause surface coarseness of amalgam restoration when used according to the directions of the manufacturer.

\section{CONCLUSION}

Based on study results and discussion, it can be concluded that there is no significant difference on the surface coarseness of high-copper amalgam restoration before and after the first and the second of $38 \%$ hydrogen peroxide application of 15 minutes using in-office bleaching technique.

\section{REFERENCES}

1. Halim H. Perawatan diskolorisasi gigi dengan teknik bleaching. Jakarta: Penerbit Univ Trisakti; 2006.

2. Grossman LI, Oliet S, Del Rio CE. IImu endodontik dalam praktek. Ed XI. Jakarta: EGC; 1995.

3. Rismanto Y, Dewayani I, Dharma RH. Dental whitening. Jakarta: Dental Lintas Mediatama. 2005.

4. McGuckin SR, Babin JF, Meyer BJ. Alterations in human enamel surface morphology following vital bleaching. J Prosthet Dent 1992 Nov;68(5):754-60.

5. Wattanapayungkul P, Yap AUJ. Effect of inoffice bleaching products on surface finish of tooth-colored restoration. Oper Dentist 
2003;28:15-9.

6. Swift Jr. RJ, Perdiago J. Effect of bleaching on teeth and restorations. Compend Contin Educ Dent 1988;19:815-20.

7. Robertello FJ, Dishman MV, Sarret DC, Aperly $A C$. The effect of home bleaching product on mercury release from admix amalgam. Am J Dent 1999;12:227-30.

8. Rotstein I, Hogan $\mathrm{H}$, Avron $\mathrm{Y}$, Shemesh $\mathrm{H}$, Steinberg D. Mercury release from dental amalgam after treatment with $10 \%$ carbamide peroxide in-vitro. Oral Surg Oral Med Oral Pathol Oral Radiol Endodont 2000;89(2):2169.

9. Canay S, Cehreli MC, Bilgic S. In vitro evaluation of the effect of a current bleaching agent on the electrochemical corrosion of dental alloys. J Oral Rehabil 2002;29:1014-9.

10. Certisimo A, Francis R, Michael D, Russel B. The effect of bleaching agent on mercury release from spherical dental amalgam. General Dentistry 2003 Jul-Aug:356-9.

11. Silva MF, Davies RM, Stewart B, DeVizio W, Tonholo J, Junior JGDS, et al. Effect of whitening gels on the surface roughness of restorative meterial in situ. Dent Mat 2006;22: 919-24.

12. Schemehorn B, Gonzalez-Cabezas C, Joiner A. A SEM evaluation of a $6 \%$ hydrogen peroxide tooth-whitening gel on dental material in vitro. [cited 2007 Sep 14]. Available from: http: / /www.ncbi.nlm.nih.gov.

13. Ahn HJ, Song KB, Lee YE, Lee YT, Cho SA, Kim
$\mathrm{KH}$. Surface change of dental amalgam after treatment with $10 \%$ carbamide peroxide 2006 [cited 2007 Sep 14]. Available from: http:// www.ncbi.nlm.nih.gov.

14. Anusavice KJ. Phillips's science dental material. $11^{\text {th }}$ ed. Philadelphia: W.B. Saunders; 2003.

15. Rotstein I, Mor C, Joel R, Arwaz. Changes in surface level of mercury, silver, tin, and copper of dental amalgam treated with carbamide peroxide and hydrogen peroxide in-vitro. Oral Surg Oral Med Oral Pathol Oral Radiol Endodont 1997;83(4):506-9.

16. Al-Salehi SH, Hatton PV, Miller CA, Mc Leod $C$, Joiner A. The effect of carbamide peroxide treatment on metal ion release from dental amalgam. Dent Mater 2006;22:948-53.

17. Rotstein I, Avron Y, Shemesh H, Dogan H, Mor C, Steinberg $D$. Factor affecting mercury release from dental amalgam exposed to carbamide peroxide bleaching agent. Am J Dent 2004 Oct;17(5):347-50.

18. Windarto S, Adisusanto W. Studi efek pemolesan tumpatan amalgam terhadap korosi. Proceeding Kongres Nasional XVI PDGI.1985.

19. Phillips RW, Moore BK. Elements of dental material. $5^{\text {th }}$ ed. Philadelphia: W.B. Saunders Co.; 1994.

20. Soh G, Chew CL, Lee AS, Yeoh TS. Significant of hydrogen ion consentration on the dissolution of mercury from dental amalgam. Quintessence Int1991 Mar;22(3):225-8. 